\title{
Cardiac Developmental Biology: From Flies to Humans
}

\author{
Ichiro SHIOJIMA and Issei KOMURO \\ Department of Cardiovascular Science and Medicine, Chiba University Graduate School of \\ Medicine, Chiba, Japan
}

\begin{abstract}
The heart is the first organ to form during embryogenesis, and heart formation is essential for subsequent embryonic development. Since the identification of a cardiac-restricted transcription factor Csx/Nkx-2.5 in the early 1990s, extensive studies on cardiac development have been done in various species ranging from flies to hu-
\end{abstract}

mans. Molecular dissection of regulatory pathways that control multiple steps of cardiogenesis will not only advance our understanding of cardiac development and congenital heart diseases, but will also provide an important clue to novel therapeutic strategies for heart diseases. [The Japanese Journal of Physiology 55: 245-254, 2005]
The heart is the first organ to form during embryonic development, and the supplementation of oxygen and nutrients via the vascular system following heart formation is critical to embryogenesis. Classical embryology, in which morphological studies or tissue transplantation experiments were predominantly performed, has explored the precise timing and location of organogenesis and the interactions between different tissues or germ layers that are required for the proper formation of specific organs. However, little information has been provided by such studies regarding molecules or signaling pathways that regulate specific organ development during embryogenesis. The identification of a cardiac-restricted transcription factor Csx/Nkx-2.5 more than a decade ago prompted a number of researchers to investigate the molecular mechanisms of cardiac development, leading to a great advance in our understanding of the signaling molecules, transcription factors, and growth factors that participate in multiple steps of cardiogenesis.

\section{Cardiogenic Transcription Factors}

Tinman: a Drosophila cardiac-restricted transcription factor. In the late 1980s, the MyoD family of basic helix-loop-helix transcription factors were identified as critical master regulators of skeletal muscle differentiation [1]. Although cardiac and skel- etal muscle cells share some common features in terms of contractile protein expression, all the efforts to isolate MyoD-like transcription factors in the heart were unsuccessful. Meanwhile, a Drosophila gene called $N K-4 / m s h-2$ was reported to be expressed predominantly in the heart [2]. Drosophila heart is formed on the dorsal side of the embryo by the fusion of a pair of heart primordia (cardiac mesoderm) that originates from the dorsal most part of the mesoderm. Unlike mammalian heart, the mature fly heart is a tube-like structure (also called "dorsal vessel") in which cardial cells form the inner layer and pericardial cells form the outer layer of the tubular structure (Fig. 1). Drosophila has an open circulatory system, and the dorsal vessel pumps the hemolymph from tail-to-head orientation by rhythmical contraction. $N K-4 / m s h-2$ is expressed in the entire mesoderm in the early stage of development, and subsequently its expression becomes restricted to cardiac mesoderm and the heart. Furthermore, it was reported in 1993 that loss-of-function mutation of $\mathrm{NK}$ 4/msh-2 results in loss of heart formation, indicating that $N K-4 / m s h-2$ is a cardiac-restricted transcription factor that is essential for Drosophila heart development $[3,4]$. NK-4/msh-2 gene was therefore re-named tinman after a character in The Wizard of $\mathrm{Oz}$ that has no heart.

Csx/Nkx-2.5: a vertebrate Tinman homolog. Following the characterization of tinman as an essen-

Received on Sep 19, 2005; accepted on Nov 8, 2005; released online on Nov 10, 2005; DOI: 10.2170/jjphysiol.M94

Correspondence should be addressed to: Issei Komuro, Department of Cardiovascular Science and Medicine, Chiba University Graduate School of Medicine, 1-8-1 Inohana, Chuo-ku, Chiba, 260-8670 Japan. Phone: +81-43-226-2097, E-mail: komuro-tky@umin. ac.jp 


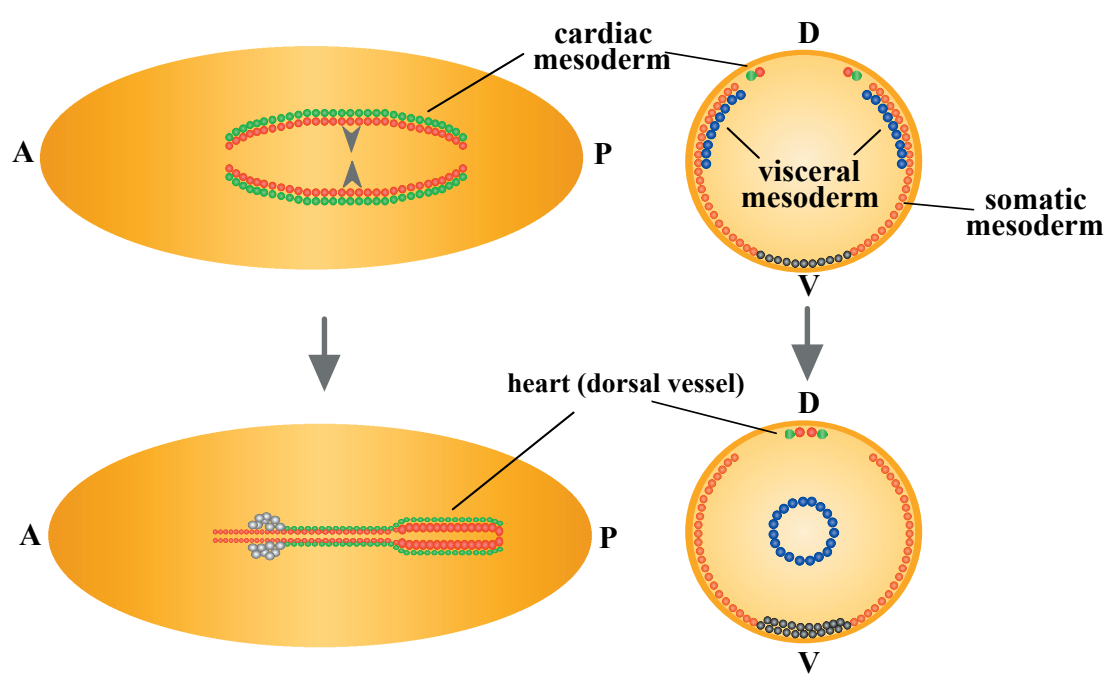

Fig. 1. Drosophila heart development. Drosophila heart precursor cells derive from the dorsal part of the mesoderm, and two heart primordia fuse in the dorsal midline to form fly heart (dorsal vessel). Cardial cells (red) constitute the inner layer and pericardial cells (green) constitute the outer layer of the heart, respectively. A, anterior; $P$, posterior; D, dorsal; V, ventral.

tial gene for fly heart formation, a murine homolog of Drosophila tinman was isolated in 1993 independently by two groups and named $C s x$ (cardiac- $\underline{s}$ pecific homeobox) or $N k x-2.5$ (hereafter referred to as $C s x /$ $N k x-2.5)[5,6]$. In vertebrates, two heart primordia are situated in the anterior lateral mesoderm (also called cardiac crescent), and they fuse at the midline on the ventral side to form a linear heart tube as a result of lateral-to-ventral folding of the embryo. Subsequently, the linear heart tube undergoes rightward looping and atrial/ventricular septa are formed, leading to the formation of a four-chambered heart (Fig. 2). The expression of Csx/Nkx-2.5 starts to be observed in the anterior lateral mesoderm at embryonic day 7.5 and is maintained at high levels exclusively in cardiac muscle cells throughout life. The isolation of $C s x / N k x-2.5$ genes from fish, frog, chick, and human revealed that the expression pattern and amino acid sequences of Csx/Nkx-2.5 are highly conserved in evolution [7-10]. Based on this cardiac-restricted expression pattern and its homology with Drosophila tinman, Csx/Nkx2.5 was expected to be an essential gene for vertebrate heart formation. Indeed, targeted disruption of Csx/ $N k x-2.5$ resulted in embryonic lethality because of the arrested development of the heart. Detailed analyses of the hearts of mutant mice revealed that heart development was arrested at the looping stage, associated with left ventricular hypoplasia $[11,12]$. These data, on one hand, indicate that Csx/Nkx-2.5 is essential for vertebrate heart development. On the other hand, however, unlike tinman mutant in flies, differentiation of mesodermal cells into cardiomyocytes was not greatly affected (except for several genes such as myosin light chain $2 v$, whose expression was reduced in Csx/Nkx-2.5 mutant mice). Because several tinman- related genes besides $C s x / N k x-2.5$ have been identified in vertebrate genomes, the phenotypic differences between tinman mutant flies (no heart formation) and Csx/Nkx-2.5 mutant mice (abnormal morphogenesis of the heart) may be due to genetic redundancy among these tinman-related genes in mice. Supporting this notion is the finding that injection of Xenopus embryos with a dominant-negative form of Csx/ $\mathrm{Nkx}-2.5$ (which is expected to inhibit the functions of several tinman-related genes including $C s x / N k x-2.5)$ results in a complete loss of heart formation [13]. Another possibility is that tinman and Csx/Nkx-2.5 diverged in terms of their functional roles in cardiogenesis during evolution, because expression of Csx/Nkx-2.5 in tinman mutant flies failed to rescue the defective cardiac development $[14,15]$.

GATA-4/5/6 and Drosophila pannier. GATA$4 / 5 / 6$ belong to a subfamily of zinc-finger containing GATA transcription factors and are expressed predominantly in the heart and gut [16]. Like Csx/Nkx-2.5, GATA-4 starts to be expressed in cardiac mesoderm at around E7.5 and continues to be expressed in the heart at high levels. The identification of functional GATA binding sites in the regulatory region of several cardiac-specific genes have strongly suggested the essential roles of GATA-4/5/6 in heart development and cardiacspecific gene expression. However, targeted disruption of mouse GATA-4 gene resulted in embryonic lethality and abnormal cardiac morphogenesis (cardia bifida: two hearts on both sides of the embryo) because of a defect in ventral fusion of the embryo $[17,18]$. In these mutants, most of cardiac-specific genes were expressed regardless of the abnormal morphology of the heart. GATA-5 knockout mice exhibited no cardiac defects [19], and GATA-6 null mice die during early em- 

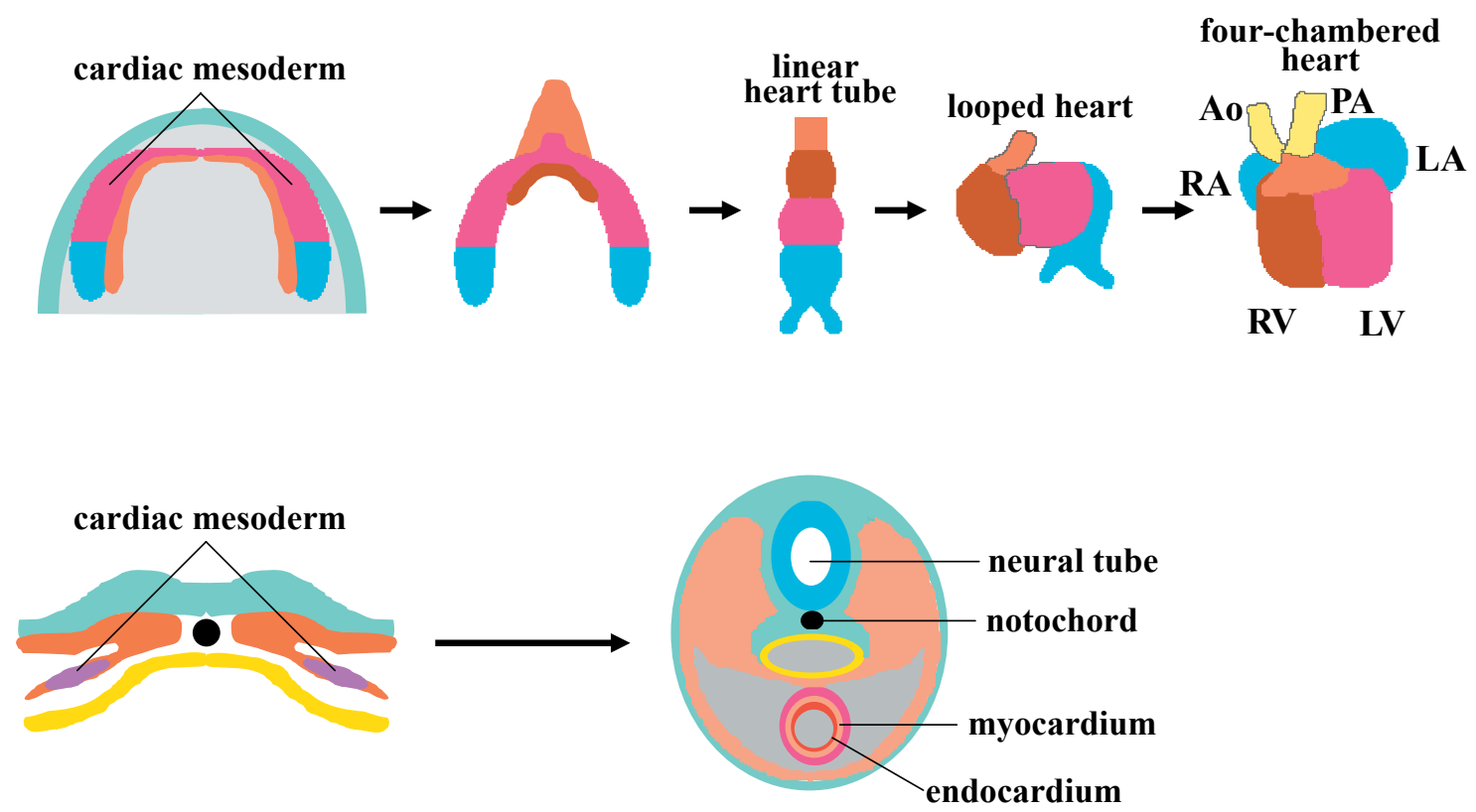

Fig. 2. Vertebrate heart development. Heart precursor cells are derived from the anterior lateral mesoderm (cardiac mesoderm), and two heart primordia fuse in the ventral midline to form the linear heart tube. At this stage, cardiac chamber specificity is already determined along the anteri- or-posterior axis, where the future left ventricle and atria are situated in the posterior part of the linear heart tube. After rightward looping and septum formation, a four-chambered heart is formed. Ao, aorta; PA, pulmonary artery; RA, right atrium; $L A$, left atrium; $R V$, right ventricle; $L V$, left ventricle. bryonic development (E5.5-7.5), making it difficult to evaluate the role of GATA- 6 during heart development $[20,21]$. Of note, zebrafish with mutations for GATA-5 gene exhibit similar phenotypes with mouse GATA-4 knockouts (i.e., cardia bifida) as a result of defective endoderm formation [22], suggesting that there was a reversal of the roles of GATA- 4 and GATA- 5 between fish and mice during evolution.

In Drosophila, a GATA family of transcription factor called Pannier is expressed in cardiac mesoderm and the heart. A loss-of-function mutation of pannier results in the lack of cardial cells, whereas overexpression of Pannier increases the number of cardial cells. Co-expression of Tinman and Pannier further enhances the effects of Pannier overexpression. Functional substitution of Pannier by mouse GATA-4 was also demonstrated [23]. These findings indicate that pannier is an essential gene for heart development in flies and suggest that its function is related to vertebrate GATA-4 gene. They also suggest the existence of a synergistic interaction between Tinman and Pannier. Likewise, physical interaction and synergistic action on downstream target genes have been reported on Csx/Nkx-2.5 and GATA-4 [24-28]. Besides these physical and synergistic interactions, there are upstream-downstream genetic relationships between Tinman/Csx/Nkx-2.5 and Pannier/GATA-4/5/6: (i) pannier is a direct target of Tinman, and pannier expression is induced by Tinman [29]; (ii) $C s x / N k x-2.5$ promoter contains functional GATA binding sites and is transactivated by GATA-4/5/6 [30, 31]; and (iii) GATA-6 promoter, on the other hand, is transactivated by Csx/Nkx-2.5 [32, 33]. These genetic relationships between Csx/Nkx-2.5 and GATA family of transcription factors presumably provide a framework for mutually reinforcing regulatory network that maintains the expression of cardiogenic transcription factors once mesodermal cells are committed to a cardiac lineage.

D-MEF2 and MEF2C. MEF2 belongs to a family of MADS-box containing transcription factors. Mammalian genomes contain four $M E F 2$ genes (MEF2A$D$ ), and Drosophila has a single MEF2 gene, D-mef2. During the early stage of embryogenesis, D-mef2 is expressed in the entire mesoderm, and subsequently its expression is restricted to somatic and visceral muscle precursor cells. In the heart, $D-m e f 2$ is expressed in cardial cells in the later stage of development $[34,35]$. $D$-mef 2 gene is a direct target of Tinman and Pannier, and the expression of $D$-mef 2 in cardial cells is regulated by these factors $[29,36]$. In $D$-mef 2 mutant flies, although a heart-like structure is formed, the differentiation and maturation of cardial cells are disturbed, and the expressions of contractile proteins in the heart are missing [37]. Thus D-MEF2 controls cardiomyo- 


\section{SHIOJIMA and I. KOMURO}

cyte terminal differentiation in Drosophila heart.

In mice, targeted disruption of $M E F 2 C$ results in embryonic lethality because of right ventricular hypoplasia [38]. In these animals, the expressions of several contractile protein genes are reduced, suggesting that MEF2C plays a similar role in mice with D-MEF2 in Drosophila in the control of cardiomyocyte terminal differentiation. In contrast, $M E F 2 A$ mutant mice exhibit sudden cardiac death resulting from mitochondrial defects [39], and $M E F 2 B$ mutant mice exhibit no major phenotypes [40]. Since the expression patterns of $M E F 2 A-D$ are grossly overlapping and DNA binding affinity and specificity to MEF2 elements are similar among these factors, the precise mechanisms by which deletion of different MEF2 factors have divergent effects are now unclear. Although $M E F 2 C$ expression is reduced in $C s x / N k x-2.5$ knockout mice [12], it is also unclear whether $M E F 2$ genes are direct downstream targets of Csx/Nkx-2.5 and/or GATA factors in mice, as is the case in flies.

SRF, myocardin, and Hop. Serum response factor (SRF) is another MADS-box containing transcription factor that binds to the core sequence of a serum response element/CArG box $\left(\mathrm{CC}[\mathrm{A} / \mathrm{T}]_{6} \mathrm{GG}\right)$. Although SRF is not a cardiac-restricted transcription factor, functional CArG elements have been identified in several cardiac-specific genes. Further, SRF is preferentially expressed in cardiac mesoderm during the early stage of embryogenesis [41]. It also physically interacts with Csx/Nkx-2.5 or GATA-4 and coordinately regulates downstream target genes $[42,43]$. These findings have suggested important roles for SRF in heart development and cardiac-specific gene expression. Indeed, cardiac muscle cell-specific SRF knockout resulted in embryonic lethality because of abnormal cardiac morphogenesis associated with reduced expression of Csx/Nkx-2.5 and GATA-4, indicating that SRF is also required for normal heart development [44]. Myocardin and Hop were identified as SRF co-factors, and myocardin positively regulates SRF-dependent transcription, whereas Hop negatively regulates it [45-47]. Overexpression of dominant-negative myocardin in Xenopus results in a loss of heart formation, whereas myocardin knockout mice exhibit no cardiac phenotype $[45,48]$. This apparent discrepancy is presumably due to the genetic redundancies between myocardin and myocardin-related transcription factors in the heart [49].

Hand1/eHand and Hand2/dHand. Hand1/ eHand and Hand $2 / \mathrm{dHand}$ belong to a family of basic helix-loop-helix transcription factors and are ex- pressed in cardiac mesoderm during embryogenesis. Subsequently, the expression of Handl becomes restricted to a future left ventricle, whereas that of Hand2 becomes restricted to a future right ventricle [50]. Targeted disruption of Hand 2 results in embryonic lethality resulting from right ventricular hypoplasia that is similar to $M E F 2 C$ knockout phenotype [51]. Handl deletion results in early embryonic lethality because of placental defect, making it difficult to explore the role of Hand1 in cardiac development $[52,53]$. However, Handl null embryos obtained by tetraploid rescue to bypass the placental defect exhibit a cardiac phenotype similar to that of $C s x / N k x-2.5$ knockout mice (left ventricular hypoplasia) [53]. Consistent with this, Handl expression is reduced in $C s x / N k x-2.5$ mutant mice [12]. Furthermore, combined deletion of Hand 2 and Csx/Nkx-2.5 results in hypoplasia of both ventricles [54]. Taken together, these findings suggest that Hand genes are important for ventricular chamber specification and that Hand 1 and Hand 2 play critical roles in the formation of left and right ventricles, respectively. Cooperative regulations of target genes through physical interactions between Hand2 and Csx/Nkx-2.5 or GATA-4 have also been reported $[55,56]$, suggesting the existence of complex protein-protein interactions among multiple transcription factors in the regulation of cardiac development and cardiac-specific gene expression.

Tbx5 and Tbx20. Tbx5 belongs to a family of Tbox transcription factors and was originally identified as a gene mutated in Holt-Oram syndrome with congenital cardiac defects and/or limb deformity [57, 58]. Tbx 5 is expressed in the entire cardiac mesoderm during the early stage of development, and subsequently its expression becomes restricted to the posterior region of the heart (i.e., left ventricle and atria) [59]. Targeted disruption of Tbx5 in mice results in hypoplasia of the region where $T b x 5$ is normally expressed [60], indicating that $T b x 5$ is critical to the formation of the "posterior" part of the heart. Although the expressions of Csx/Nkx-2.5 and GATA-4 are reduced in Tbx 5 mutant mice, it is unclear whether these genes are direct targets of Tbx5. Tbx 5 physically interacts with Csx $/ N k x-2.5$ and synergistically transactivates downstream target genes $[60,61]$. Tbx20 is another member of T-box transcription factors that is expressed in cardiac mesoderm and developing heart. At the stage when $\operatorname{Tbx} 5$ expression is restricted to the posterior part of the heart, $T b \times 20$ is still expressed throughout the entire heart tube, including the outflow tract [62]. Targeted disruption of $T b \times 20$ results in embryonic 

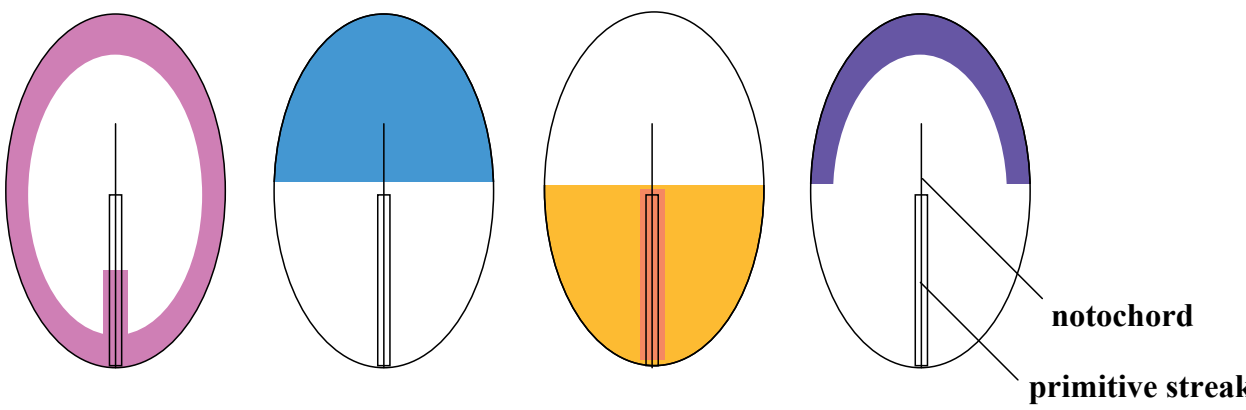

$\square$ BMP

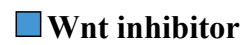

$\square$ Wnt

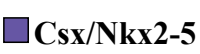

Fig. 3. Induction of Csx/ Nkx-2.5 expression by combined BMP and Wnt signals. During early chick embryogenesis, BMP is expressed in primitive streak and endoderm/ectoderm in the lateral side of the embryo. At the same developmental stage, Wnt inhibitors are expressed in the anterior part, whereas Wnts are expressed in the posterior part of the embryo, respectively. Because BMP induces and Wnt inhibits Csx/Nkx-2.5 expression, the expression domain of Csx/Nkx-2.5 is restricted to the anterior lateral mesoderm where BMP and Wnt inhibitors are co-expressed.

lethality with perturbed cardiac morphogenesis [63$66]$. Of note, $T b x 2$ is ectopically expressed in the entire heart-forming region in $T b \times 20$ null mice. $T b x 2$ is also a member of the T-box family normally expressed prominently in the atrioventricular (AV) canal, where it has been proposed to repress chamber-specific genes. These findings suggest that $T b \times 20$ represses another transcriptional repressor $T b x 2$ to induce normal chamber specification and differentiation. Consistent with this notion, Tbx5 activates whereas Tbx20 represses cardiac-specific promoters such as atrial natriuretic peptide gene [62].

\section{Cardiogenic Growth Factors}

Interactions between different tissues or germ layers play important roles in organ development during embryogenesis. Using $C s x / N k x-2.5$ as a marker of cells committed to cardiomyocytes, it has been shown that soluble factors secreted from adjacent endodermal or ectodermal tissues are critical to the commitment of mesodermal cells into a cardiac lineage.

Dpp and BMP. In flies, decapentaplegic (Dpp) has been identified as a soluble factor that is capable of inducing tinman expression in the mesoderm. Dpp belongs to a TGF- $\beta$ superfamily of growth factors and is most closely related to vertebrate bone morphogenetic protein (BMP)-2 and BMP-4. In the early stage of Drosophila embryogenesis, $d p p$ is expressed in the dorsal ectoderm adjacent to the tinman expression domain in dorsal cardiac mesoderm [67]. Dpp mutant flies fail to maintain tinman expression in the dorsal mesoderm, whereas ectopic expression of Dpp in the ventral ectoderm results in the expansion of the tinman expression domain [67], indicating that Dpp is required for proper tinman expression in dorsal cardiac mesoderm. In chick embryos, BMP-2 is expressed in the anterior lateral endoderm (Fig. 3). The ectopic expression of BMP-2 in the anterior medial mesoderm (where Csx/Nkx-2.5 is not normally expressed) induces ectopic Csx/Nkx-2.5 expression [68]. These data suggest the existence of signaling mechanisms conserved between invertebrates and vertebrates by which Dpp/BMP induces tinman/Csx/Nkx-2.5 expression in cardiac mesoderm. Among the signaling pathways downstream of BMP, Smad- and TAK1-dependent pathways have been implicated in the induction of Csx/Nkx-2.5 by BMP $[69,70]$.

Wg/Wnt and Wnt inhibitors. Wingless (Wg) in flies and the closely related Wnt ligands in vertebrates comprise a large family of secreted factors and play important roles in multiple aspects of embryogenesis. Drosophila Wg is required for the induction of cardiac mesoderm, because elimination of $\mathrm{Wg}$ function for a short time period after gastrulation using temperature sensitive wg mutant flies results in a selective loss of heart precursor cells [71]. This effect of Wg on heart development is mediated by the canonical Wnt pathway that leads to the activation of $\beta$-catenin/TCFdependent transcription [72]. However, the regulation of heart development by Wnt signaling is rather complicated in vertebrates. In chick embryos, Wnt inhibitors expressed in the anterior part of the embryo are required for heart formation by suppressing canonical Wnt activity in the posterior part of the embryo [73]. Wnt signals from neural tube have also been shown to block heart formation in the anterior paraxial mesoderm [74]. In Xenopus embryos, ectopic expression of Wnt antagonist induces ectopic heart formation in non-precardiac mesoderm, while expression of Wnt ligands inhibits heart formation [75]. Based on these findings, it was proposed that Wnt signals are negative regulators of cardiac development and that Csx/NkX2.5 is expressed in the region where BMP and Wnt inhibitors are co-expressed (Fig. 3). In contrast to these observations, non-canonical Wnt signals activated by 
Table 1. Roles of cardiogenic transcription factors during embryogenesis as revealed by gene targeting.

\begin{tabular}{ll}
\hline Transcription factor & Roles of cardiogenic transcription factors during embryogenesis \\
\hline Csx/Nkx-2.5 & Heart development, pharyngeal endoderm development \\
GATA-4/5/6 & Ventral fusion of the embryo, visceral endoderm formation \\
MEF-2C & Heart development, vascular development \\
SRF & Primitive streak formation, heart and skeletal muscle development \\
Hand & Heart development, limb development, autonomic nervous system formation \\
Tbx5 & Heart development, limb development \\
\hline
\end{tabular}

Wnt-11 are required for heart formation in Xenopus [76], and canonical Wnt signals are essential for in vitro differentiation of P19CL6 cells into cardiomyocytes $[77,78]$. Taken together, although it is difficult to reconcile these apparently paradoxical observations in various species, one possible explanation is that $\mathrm{Wg} / \mathrm{Wnt}$ signals at different developmental stages may have both positive and negative effects on cardiac development. The differential effects of canonical and non-canonical Wnt signals on heart development should also be taken into consideration.

FGF and FGF receptors. Drosophila has two fibroblast growth factor (FGF) receptors, and one is called Heartless. It can be seen from this nomenclature that heart formation is defective in heartless mutant flies [79, 80]. This phenotype, however, is thought to be due to a defect in migration of mesodermal cells. In fish, $f g f 8$ loss-of-function mutation results in a severe perturbation of heart development with reduced expressions of $C s x / N k x-2.5$ and GATA-4, suggesting that FGF signals are directly involved in zebrafish heart formation [81]. In chick embryos, FGF8 is expressed in the endoderm adjacent to the cardiac mesoderm. Expression of FGF8 can induce ectopic Csx/Nkx-2.5 expression lateral to the heart field [82], suggesting that FGF signaling is capable of inducing heart formation in association with BMP signaling. Whether FGF signaling is required for cardiogenesis awaits further investigations.

\section{Human Heart Diseases and Cardiogenic Transcription Factors}

Several cardiogenic transcription factors have been implicated in human congenital heart diseases. Linkage analysis and candidate gene approach have identified human $C S X / N K X-2.5$ as a causative gene for some forms of autosomal dominant familial heart diseases. More than 10 disease-related mutations in human $C S X / N K X-2.5$ gene have been reported, and clinical manifestations of patients with these mutations

\section{undifferentiated mesoderm} Nkx-like factors? $\longleftarrow \begin{aligned} & \text { BMP } \\ & \text { Wnt }\end{aligned}$

cardiac mesoderm

Csx/Nkx 2.5

GATA

MEF2

heart tube formation/looping

Csx/ Nkx2.5

TBX

HAND

\section{chamber specification/septation}

Csx/Nkx2.5

TBX

SRF

\section{chamber maturation}

Csx/Nkx2.5

\section{conduction system formation}

Fig. 4. Cardiogenic transcription factors and growth factors. Each step of heart formation during embryogenesis is shown by boxes, and transcription factors and growth factors implicated in distinct steps during cardiogenesis are indicated beside the arrows.

are rather divergent, including atrial septal defect, AV block, tetralogy of Fallot, ventricular septal defect, and hypertrophic cardiomyopathy [83-92]. Even in members of the same family with identical point mutations, the phenotypes are sometimes divergent, suggesting the existence of some modifier genes. Ventricular myocyte-specific Csx/Nkx-2.5 deletion in mice results in hyper-trabeculation with $\mathrm{AV}$ conduction defect, and upregulation of BMP-10 in these animals appears to 
be the underlying mechanism for accelerated trabecular formation [93]. As mentioned earlier, $T B X 5$ is a causative gene for Holt-Oram syndrome in humans, and cooperative transcriptional regulation between Tbx 5 and Csx/Nkx-2.5 has been reported. Some HoltOram patients exhibit minimal cardiac anomaly with severe limb deformity, while others have extensive cardiac anomaly with minimal limb phenotype. Of note, TBX5 mutants associated with the former group retain cooperative interactions with $\mathrm{CSX} / \mathrm{NKX}-2.5$, whereas those associated with the latter group lack such synergistic interactions [61], suggesting that the disruption of TBX5-CSX/NKX-2.5 interactions may contribute to cardiac defects in Holt-Oram syndrome patients. Mutations in human GATA-4 gene have also been identified as the cause of congenital heart diseases, including atrial septal defect [94]. Introduction of disease mutations in GATA-4 results in decreased DNA binding, decreased transcriptional activity, and, notably, loss of cooperative interactions with $T B X 5$ [94]. Collectively, these observations demonstrate the critical roles of cardiogenic transcription factors in later stages of cardiac development. Given the essential roles of these transcription factors in the early stage of heart development, these findings indicate that cardiogenic transcription factors such as $\mathrm{Csx} / \mathrm{Nkx}-2.5$, GATA-4, and Tbx5 play critical roles at multiple steps in cardiac development. They also suggest that physical interactions and transcriptional co-operations between these transcription factors are essential for normal heart development in vivo.

\section{Summary and Conclusion}

Since the identification of Csx/Nkx-2.5 as a cardiac-restricted transcription factor, there was a great advancement in our understanding of individual molecules implicated in cardiac development and cardiomyocyte differentiation, and several transcription factors and soluble factors that are critical to heart development have been identified (Fig. 4 and Table 1). However, we still do not know how these players cooperatively regulate multiple steps of cardiogenesis. Moreover, accumulating evidence suggests that the heart has substantial regenerative capacity, in part through the contribution of resident or bone marrow-derived stem cell population. It is highly conceivable that insights gained from cardiac developmental biology will also provide valuable information on the regulatory mechanisms of stem cell-based cardiac regeneration.

\section{REFERENCES}

1. Weintraub $\mathrm{H}$ : The MyoD family and myogenesis: redundancy, networks, and thresholds. Cell 75: 1241-1244, 1993

2. Bodmer R, Jan LY, and Jan YN: A new homeobox-containing gene, $m s h-2$, is transiently expressed early during mesoderm formation of Drosophila. Development 110: 661-669, 1990

3. Azpiazu N and Frasch M: tinman and bagpipe: two homeo box genes that determine cell fates in the dorsal mesoderm of Drosophila. Genes Dev 7: 1325-1340, 1993

4. Bodmer R: The gene tinman is required for specification of the heart and visceral muscles in Drosophila. Development 118: 719-729, 1993

5. Komuro I and Izumo S: Csx: a murine homeobox-containing gene specifically expressed in the developing heart. Proc Natl Acad Sci USA 90: 8145-8149, 1993

6. Lints TJ, Parsons LM, Hartley L, Lyons I, and Harvey RP: Nkx-2.5: a novel murine homeobox gene expressed in early heart progenitor cells and their myogenic descendants. Development 119: 419-431, 1993

7. Tonissen KF, Drysdale TA, Lints TJ, Harvey RP, and Krieg PA: XNkx-2.5, a Xenopus gene related to Nkx-2.5 and tinman: evidence for a conserved role in cardiac development. Dev Biol 162: 325-328, 1994

8. Chen JN and Fishman MC: Zebrafish tinman homolog demarcates the heart field and initiates myocardial differentiation. Development 122: 3809-3816, 1996

9. Schultheiss TM, Xydas S, and Lassar AB: Induction of avian cardiac myogenesis by anterior endoderm. Development 121: 4203-4214, 1995

10. Shiojima I, Komuro I, Mizuno T, Aikawa R, Akazawa $H$, Oka T, Yamazaki T, and Yazaki Y: Molecular cloning and characterization of human cardiac homeobox gene CSX1. Circ Res 79: 920-929, 1996

11. Lyons I, Parsons LM, Hartley L, Li R, Andrews JE, Robb $L$, and Harvey RP: Myogenic and morphogenetic defects in the heart tubes of murine embryos lacking the homeo box gene Nkx2-5. Genes Dev 9: 1654-1666, 1995

12. Tanaka M, Chen Z, Bartunkova S, Yamasaki N, and Izumo S: The cardiac homeobox gene Csx/Nkx2.5 lies genetically upstream of multiple genes essential for heart development. Development 126: 1269-1280, 1999

13. Fu Y, Yan W, Mohun TJ, and Evans SM: Vertebrate tinman homologues XNkx2-3 and XNkx2-5 are required for heart formation in a functionally redundant manner. Development 125: 4439-4449, 1998

14. Park M, Lewis C, Turbay D, Chung A, Chen JN, Evans S, Breitbart RE, Fishman MC, Izumo S, and Bodmer R: Differential rescue of visceral and cardiac defects in Drosophila by vertebrate tinman-related genes. Proc Natl Acad Sci USA 95: 9366-9371, 1998

15. Ranganayakulu G, Elliott DA, Harvey RP, and Olson EN: Divergent roles for NK-2 class homeobox genes in cardiogenesis in flies and mice. Development 125: 3037-3048, 1998

16. Molkentin JD: The zinc finger-containing transcription factors GATA-4, -5, and -6. Ubiquitously expressed reg- 


\section{SHIOJIMA and I. KOMURO}

ulators of tissue-specific gene expression. J Biol Chem 275: 38949-38952, 2000

17. Molkentin JD, Lin Q, Duncan SA, and Olson EN: Requirement of the transcription factor GATA4 for heart tube formation and ventral morphogenesis. Genes Dev 11: 1061-1072, 1997

18. Kuo CT, Morrisey EE, Anandappa R, Sigrist K, Lu MM, Parmacek MS, Soudais C, and Leiden JM: GATA4 transcription factor is required for ventral morphogenesis and heart tube formation. Genes Dev 11: 1048-1060, 1997

19. Molkentin JD, Tymitz KM, Richardson JA, and Olson EN: Abnormalities of the genitourinary tract in female mice lacking GATA5. Mol Cell Biol 20: 5256-5260, 2000

20. Morrisey EE, Tang Z, Sigrist K, Lu MM, Jiang F, Ip HS, and Parmacek MS: GATA6 regulates HNF4 and is required for differentiation of visceral endoderm in the mouse embryo. Genes Dev 12: 3579-3590, 1998

21. Koutsourakis $M$, Langeveld $A$, Patient $R$, Beddington $\mathrm{R}$, and Grosveld F: The transcription factor GATA6 is essential for early extraembryonic development. Development 126: 723-732, 1999

22. Reiter JF, Alexander J, Rodaway A, Yelon D, Patient R, Holder N, and Stainier DY: Gata5 is required for the development of the heart and endoderm in zebrafish. Genes Dev 13: 2983-2995, 1999

23. Gajewski K, Fossett N, Molkentin JD, and Schulz RA: The zinc finger proteins Pannier and GATA4 function as cardiogenic factors in Drosophila. Development 126: 5679-5688, 1999

24. Durocher D, Charron F, Warren R, Schwartz RJ, and Nemer M: The cardiac transcription factors Nkx2-5 and GATA-4 are mutual cofactors. EMBO J 16: 5687-5696, 1997

25. Sepulveda JL, Belaguli N, Nigam V, Chen CY, Nemer $M$, and Schwartz RJ: GATA-4 and Nkx-2.5 coactivate Nkx-2 DNA binding targets: role for regulating early cardiac gene expression. Mol Cell Biol 18: 3405-3415, 1998

26. Lee Y, Shioi T, Kasahara H, Jobe SM, Wiese RJ, Markham $\mathrm{BE}$, and Izumo S: The cardiac tissue-restricted homeobox protein Csx/Nkx2.5 physically associates with the zinc finger protein GATA4 and cooperatively activates atrial natriuretic factor gene expression. Mol Cell Biol 18: 3120-3129, 1998

27. Shiojima I, Komuro I, Oka T, Hiroi Y, Mizuno T, Takimoto E, Monzen K, Aikawa R, Akazawa H, Yamazaki T, Kudoh S, and Yazaki Y: Context-dependent transcriptional cooperation mediated by cardiac transcription factors Csx/Nkx-2.5 and GATA-4. J Biol Chem 274: 8231-8239, 1999

28. Akazawa H, Kudoh S, Mochizuki N, Takekoshi N, Takano H, Nagai T, and Komuro I: A novel LIM protein Cal promotes cardiac differentiation by association with CSX/NKX2-5. J Cell Biol 164: 395-405, 2004

29. Gajewski K, Zhang Q, Choi CY, Fossett N, Dang A, Kim $\mathrm{YH}$, Kim Y, and Schulz RA: Pannier is a transcriptional target and partner of Tinman during Drosophila cardiogenesis. Dev Biol 233: 425-436, 2001

30. Searcy RD, Vincent EB, Liberatore CM, and Yutzey KE: A GATA-dependent nkx-2.5 regulatory element activates early cardiac gene expression in transgenic mice. Development 125: 4461-4470, 1998

31. Lien CL, Wu C, Mercer B, Webb R, Richardson JA, and Olson EN: Control of early cardiac-specific transcription of Nkx2-5 by a GATA-dependent enhancer. Development 126: 75-84, 1999

32. Davis DL, Wessels A, and Burch JB: An Nkx-dependent enhancer regulates CGATA-6 gene expression during early stages of heart development. Dev Biol 217: 310-322, 2000

33. Molkentin JD, Antos C, Mercer B, Taigen T, Miano JM, and Olson EN: Direct activation of a GATA6 cardiac enhancer by Nkx2.5: evidence for a reinforcing regulatory network of Nkx2.5 and GATA transcription factors in the developing heart. Dev Biol 217: 301-309, 2000

34. Nguyen HT, Bodmer R, Abmayr SM, McDermott JC, and Spoerel NA: D-mef2: a Drosophila mesoderm-specific MADS box-containing gene with a biphasic expression profile during embryogenesis. Proc Natl Acad Sci USA 91: 7520-7524, 1994

35. Lilly B, Galewsky S, Firulli AB, Schulz RA, and Olson EN: D-MEF2: a MADS box transcription factor expressed in differentiating mesoderm and muscle cell lineages during Drosophila embryogenesis. Proc Natl Acad Sci USA 91: 5662-5666, 1994

36. Gajewski K, Kim Y, Lee YM, Olson EN, and Schulz RA: D-mef2 is a target for Tinman activation during Drosophila heart development. EMBO J 16: 515-522, 1997

37. Lilly B, Zhao B, Ranganayakulu G, Paterson BM, Schulz $\mathrm{RA}$, and Olson EN: Requirement of MADS domain transcription factor D-MEF2 for muscle formation in Drosophila. Science 267: 688-693, 1995

38. Lin Q, Schwarz J, Bucana C, and Olson EN: Control of mouse cardiac morphogenesis and myogenesis by transcription factor MEF2C. Science 276: 1404-1407, 1997

39. Naya FJ, Black BL, Wu H, Bassel-Duby R, Richardson JA, Hill JA, and Olson EN: Mitochondrial deficiency and cardiac sudden death in mice lacking the MEF2A transcription factor. Nat Med 8: 1303-1309, 2002

40. Molkentin JD, Firulli AB, Black BL, Martin JF, Hustad CM, Copeland N, Jenkins N, Lyons G, and Olson EN: MEF2B is a potent transactivator expressed in early myogenic lineages. Mol Cell Biol 16: 3814-3824, 1996

41. Sepulveda JL, Vlahopoulos S, Iyer D, Belaguli N, and Schwartz RJ: Combinatorial expression of GATA4, Nkx2-5, and serum response factor directs early cardiac gene activity. J Biol Chem 277: 25775-25782, 2002

42. Chen CY and Schwartz RJ: Recruitment of the tinman homolog Nkx-2.5 by serum response factor activates cardiac alpha-actin gene transcription. Mol Cell Biol 16: 6372-6384, 1996

43. Belaguli NS, Sepulveda JL, Nigam V, Charron F, Nemer $\mathrm{M}$, and Schwartz RJ: Cardiac tissue enriched factors serum response factor and GATA-4 are mutual coregulators. Mol Cell Biol 20: 7550-7558, 2000

44. Parlakian A, Tuil D, Hamard G, Tavernier G, Hentzen D, Concordet JP, Paulin D, Li Z, and Daegelen D: Targeted inactivation of serum response factor in the developing heart results in myocardial defects and embryonic 
lethality. Mol Cell Biol 24: 5281-5289, 2004

45. Wang D, Chang PS, Wang Z, Sutherland L, Richardson JA, Small E, Krieg PA, and Olson EN: Activation of cardiac gene expression by myocardin, a transcriptional cofactor for serum response factor. Cell 105: 851-862, 2001

46. Chen F, Kook H, Milewski R, Gitler AD, Lu MM, Li J, Nazarian R, Schnepp R, Jen K, Biben C, Runke G, Mackay JP, Novotny J, Schwartz RJ, Harvey RP, Mullins MC, and Epstein JA: Hop is an unusual homeobox gene that modulates cardiac development. Cell 110: 713-723, 2002

47. Shin $\mathrm{CH}$, Liu ZP, Passier R, Zhang CL, Wang DZ, Harris TM, Yamagishi H, Richardson JA, Childs G, and Olson EN: Modulation of cardiac growth and development by HOP, an unusual homeodomain protein. Cell 110: 725-735, 2002

48. Li S, Wang DZ, Wang Z, Richardson JA, and Olson EN: The serum response factor coactivator myocardin is required for vascular smooth muscle development. Proc Natl Acad Sci USA 100: 9366-9370, 2003

49. Wang DZ, Li S, Hockemeyer D, Sutherland L, Wang Z, Schratt G, Richardson JA, Nordheim A, and Olson EN: Potentiation of serum response factor activity by a family of myocardin-related transcription factors. Proc Natl Acad Sci USA 99: 14855-14860, 2002

50. Firulli AB: A HANDful of questions: the molecular biology of the heart and neural crest derivatives (HAND)subclass of basic helix-loop-helix transcription factors. Gene 312: 27-40, 2003

51. Srivastava D, Thomas T, Lin Q, Kirby ML, Brown D, and Olson EN: Regulation of cardiac mesodermal and neural crest development by the bHLH transcription factor, dHAND. Nat Genet 16: 154-160, 1997

52. Firulli $A B$, McFadden DG, Lin $Q$, Srivastava $D$, and $O I-$ son EN: Heart and extra-embryonic mesodermal defects in mouse embryos lacking the bHLH transcription factor Hand1. Nat Genet 18: 266-270, 1998

53. Riley P, Anson-Cartwright L, and Cross JC: The Hand 1 bHLH transcription factor is essential for placentation and cardiac morphogenesis. Nat Genet 18: 271-275, 1998

54. Yamagishi H, Yamagishi $\mathrm{C}$, Nakagawa O, Harvey RP, Olson EN, and Srivastava D: The combinatorial activities of Nkx2.5 and dHAND are essential for cardiac ventricle formation. Dev Biol 239: 190-203, 2001

55. Dai YS, Cserjesi P, Markham BE, and Molkentin JD: The transcription factors GATA4 and dHAND physically interact to synergistically activate cardiac gene expression through a p300-dependent mechanism. J Biol Chem 277: 24390-24398, 2002

56. Thattaliyath BD, Firulli BA, and Firulli AB: The basic-helix-loop-helix transcription factor HAND2 directly regulates transcription of the atrial naturetic peptide gene. $J$ Mol Cell Cardiol 34: 1335-1344, 2002

57. Li QY, Newbury-Ecob RA, Terrett JA, Wilson DI, Curtis AR, Yi CH, Gebuhr T, Bullen PJ, Robson SC, Strachan T, Bonnet D, Lyonnet S, Young ID, Raeburn JA, Buckler AJ, Law DJ, and Brook JD: Holt-Oram syndrome is caused by mutations in TBX5, a member of the Brachyury (T) gene family. Nat Genet 15: 21-29, 1997
58. Basson CT, Bachinsky DR, Lin RC, Levi T, Elkins JA, Soults J, Grayzel D, Kroumpouzou E, Traill TA, LeblancStraceski J, Renault B, Kucherlapati R, Seidman JG, and Seidman CE: Mutations in human TBX5 cause limb and cardiac malformation in Holt-Oram syndrome. Nat Genet 15: 30-35, 1997

59. Bruneau BG, Logan M, Davis N, Levi T, Tabin CJ, Seidman JG, and Seidman CE: Chamber-specific cardiac expression of $\mathrm{Tbx} 5$ and heart defects in Holt-Oram syndrome. Dev Biol 211: 100-108, 1999

60. Bruneau BG, Nemer G, Schmitt JP, Charron F, Robitaille L, Caron S, Conner DA, Gessler M, Nemer M, Seidman CE, and Seidman JG: A murine model of Holt-Oram syndrome defines roles of the T-box transcription factor Tbx5 in cardiogenesis and disease. Cell 106: 709-721, 2001

61. Hiroi Y, Kudoh S, Monzen K, Ikeda Y, Yazaki Y, Nagai $\mathrm{R}$, and Komuro I: Tbx5 associates with Nkx2-5 and synergistically promotes cardiomyocyte differentiation. Nat Genet 28: 276-280, 2001

62. Plageman TF Jr and Yutzey KE: Differential expression and function of $\mathrm{Tb} \times 5$ and $\mathrm{Tb} \times 20$ in cardiac development. J Biol Chem 279: 19026-19034, 2004

63. Cai CL, Zhou W, Yang L, Bu L, Qyang Y, Zhang X, Li $X$, Rosenfeld MG, Chen J, and Evans S: T-box genes coordinate regional rates of proliferation and regional specification during cardiogenesis. Development 132: 2475-2487, 2005

64. Takeuchi JK, Mileikovskaia M, Koshiba-Takeuchi K, Heidt AB, Mori AD, Arruda EP, Gertsenstein M, Georges R, Davidson L, Mo R, Hui CC, Henkelman RM, Nemer M, Black BL, Nagy A, and Bruneau BG: Tbx20 dosedependently regulates transcription factor networks required for mouse heart and motoneuron development. Development 132: 2463-2474, 2005

65. Stennard FA, Costa MW, Lai D, Biben C, Furtado MB, Solloway MJ, McCulley DJ, Leimena C, Preis JI, Dunwoodie SL, Elliott DE, Prall OW, Black BL, Fatkin D, and Harvey RP: Murine T-box transcription factor Tbx20 acts as a repressor during heart development, and is essential for adult heart integrity, function and adaptation. Development 132: 2451-2462, 2005

66. Singh MK, Christoffels VM, Dias JM, Trowe MO, Petry M, Schuster-Gossler K, Burger A, Ericson J, and Kispert A: Tbx20 is essential for cardiac chamber differentiation and repression of Tbx2. Development 132: 2697-2707, 2005

67. Frasch M: Induction of visceral and cardiac mesoderm by ectodermal Dpp in the early Drosophila embryo. Nature 374: 464-467, 1995

68. Schultheiss TM, Burch JB, and Lassar AB: A role for bone morphogenetic proteins in the induction of cardiac myogenesis. Genes Dev 11: 451-462, 1997

69. Monzen K, Shiojima I, Hiroi Y, Kudoh S, Oka T, Takimoto E, Hayashi D, Hosoda T, Habara-Ohkubo A, Nakaoka T, Fujita T, Yazaki Y, and Komuro I: Bone morphogenetic proteins induce cardiomyocyte differentiation through the mitogen-activated protein kinase kinase kinase TAK1 and cardiac transcription factors Csx/Nkx-2.5 and GATA-4. Mol Cell Biol 19: 7096-7105, 1999

70. Monzen K, Hiroi Y, Kudoh S, Akazawa H, Oka T, Takim- 


\section{SHIOJIMA and I. KOMURO}

oto E, Hayashi D, Hosoda T, Kawabata M, Miyazono K, Ishii S, Yazaki Y, Nagai R, and Komuro I: Smads, TAK1, and their common target ATF-2 play a critical role in cardiomyocyte differentiation. J Cell Biol 153: 687-698, 2001

71. Wu X, Golden K, and Bodmer R: Heart development in Drosophila requires the segment polarity gene wingless. Dev Biol 169: 619-628, 1995

72. Park M, Wu X, Golden K, Axelrod JD, and Bodmer R: The wingless signaling pathway is directly involved in Drosophila heart development. Dev Biol 177: 104-116, 1996

73. Marvin MJ, Di Rocco G, Gardiner A, Bush SM, and Lassar AB: Inhibition of Wnt activity induces heart formation from posterior mesoderm. Genes Dev 15: 316-327, 2001

74. Tzahor E and Lassar AB: Wnt signals from the neural tube block ectopic cardiogenesis. Genes Dev 15: 255260, 2001

75. Schneider VA and Mercola M: Wnt antagonism initiates cardiogenesis in Xenopus laevis. Genes Dev 15: 304 315, 2001

76. Pandur P, Lasche M, Eisenberg LM, and Kuhl M: Wnt11 activation of a non-canonical Wnt signalling pathway is required for cardiogenesis. Nature 418: 636-641, 2002

77. Nakamura T, Sano M, Songyang Z, and Schneider MD: A Wnt- and beta -catenin-dependent pathway for mammalian cardiac myogenesis. Proc Natl Acad Sci USA 100: 5834-5839, 2003

78. Naito AT, Akazawa $H$, Takano $H$, Minamino $T$, Nagai T, Aburatani $\mathrm{H}$, and Komuro I: Phosphatidylinositol 3kinase-Akt pathway plays a critical role in early cardiomyogenesis by regulating canonical Wnt signaling. Circ Res 97: 144-151, 2005

79. Beiman M, Shilo BZ, and Volk T: Heartless, a Drosophila FGF receptor homolog, is essential for cell migration and establishment of several mesodermal lineages. Genes Dev 10: 2993-3002, 1996

80. Gisselbrecht S, Skeath JB, Doe CQ, and Michelson AM: heartless encodes a fibroblast growth factor receptor (DFR1/DFGF-R2) involved in the directional migration of early mesodermal cells in the Drosophila embryo. Genes Dev 10: 3003-3017, 1996

81. Reifers F, Walsh EC, Leger S, Stainier DY, and Brand $\mathrm{M}$ : Induction and differentiation of the zebrafish heart requires fibroblast growth factor 8 (fgf8/acerebellar). Development 127: 225-235, 2000

82. Alsan BH and Schultheiss TM: Regulation of avian cardiogenesis by Fgf8 signaling. Development 129: 1935 1943, 2002

83. Schott JJ, Benson DW, Basson CT, Pease W, Silberbach GM, Moak JP, Maron BJ, Seidman CE, and Seidman JG: Congenital heart disease caused by mutations in the transcription factor NKX2-5. Science 281: 108-111, 1998
84. Benson DW, Silberbach GM, Kavanaugh-McHugh A, Cottrill C, Zhang Y, Riggs S, Smalls O, Johnson MC, Watson MS, Seidman JG, Seidman CE, Plowden J, and Kugler JD: Mutations in the cardiac transcription factor NKX2.5 affect diverse cardiac developmental pathways. J Clin Invest 104: 1567-1573, 1999

85. Hosoda T, Komuro I, Shiojima I, Hiroi Y, Harada M, Murakawa $Y$, Hirata $Y$, and Yazaki Y: Familial atrial septal defect and atrioventricular conduction disturbance associated with a point mutation in the cardiac homeobox gene CSX/NKX2-5 in a Japanese patient. Jpn Circ J 63: 425-426, 1999

86. Goldmuntz E, Geiger E, and Benson DW: NKX2.5 mutations in patients with tetralogy of fallot. Circulation 104: 2565-2568, 2001

87. Ikeda $Y$, Hiroi $Y$, Hosoda T, Utsunomiya T, Matsuo S, Ito T, Inoue J, Sumiyoshi T, Takano H, Nagai R, and Komuro I: Novel point mutation in the cardiac transcription factor CSX/NKX2.5 associated with congenital heart disease. Circ J 66: 561-563, 2002

88. Watanabe Y, Benson DW, Yano S, Akagi T, Yoshino $M$, and Murray JC: Two novel frameshift mutations in NKX2.5 result in novel features including visceral inversus and sinus venosus type ASD. J Med Genet 39: 807-811, 2002

89. Elliott DA, Kirk EP, Yeoh T, Chandar S, McKenzie F, TayIor P, Grossfeld P, Fatkin D, Jones O, Hayes P, Feneley $M$, and Harvey RP: Cardiac homeobox gene NKX2-5 mutations and congenital heart disease: associations with atrial septal defect and hypoplastic left heart syndrome. J Am Coll Cardiol 41: 2072-2076, 2003

90. McElhinney DB, Geiger E, Blinder J, Benson DW, and Goldmuntz E: NKX2.5 mutations in patients with congenital heart disease. J Am Coll Cardiol 42: 1650-1655, 2003

91. Reamon-Buettner SM, and Borlak J: Somatic NKX2-5 mutations as a novel mechanism of disease in complex congenital heart disease. J Med Genet 41: 684-690, 2004

92. Reamon-Buettner SM, Hecker H, Spanel-Borowski K, Craatz S, Kuenzel E, and Borlak J: Novel NKX2-5 mutations in diseased heart tissues of patients with cardiac malformations. Am J Pathol 164: 2117-2125, 2004

93. Pashmforoush M, Lu JT, Chen H, Amand TS, Kondo R, Pradervand S, Evans SM, Clark B, Feramisco JR, Giles W, Ho SY, Benson DW, Silberbach M, Shou W, and Chien KR: Nkx2-5 pathways and congenital heart disease; loss of ventricular myocyte lineage specification leads to progressive cardiomyopathy and complete heart block. Cell 117: 373-386, 2004

94. Garg V, Kathiriya IS, Barnes R, Schluterman MK, King IN, Butler CA, Rothrock CR, Eapen RS, Hirayama-Yamada K, Joo K, Matsuoka R, Cohen JC, and Srivastava D: GATA4 mutations cause human congenital heart defects and reveal an interaction with TBX5. Nature 424: 443-447, 2003 